\title{
IDENTIFIKASI DAN POTENSI GULMA DI BAWAH TEGAKAN JATI UNGGUL NUSANTARA (JUN) DI KEBUN PERCOBAAN UNIVERSITAS NUSA BANGSA, COGREG, BOGOR
}

\author{
I. G. A. Manik Widhyastini*, Nia Yuliani dan Febi Nurilmala \\ Staf Pengajar Fakultas MIPA Universitas Nusa Bangsa \\ Jl. K. H. Soleh Iskandar Km. 4, Cimanggu, Tanah Sareal - Bogor 16166 \\ Telp. 0252-8340217, 7535605 \\ *email : widhyastini0508@yahoo.com
}

\section{ABSTRACT \\ Weed Identification and Potential under the Stands o Superior Teak Nusantara (JUN) in Experiment Garden of Universityof Nusa Bangsa, Cogreg, Bogor}

\begin{abstract}
Weed is a plant that the presence is not desirable because it can reduce the results achieved by the plant production. Weeds is an important component in forest ecosystems that must be taken their role. Composition and diversity of weed will determine the forest structure that will ultimately affect the ecological function of the forest. The presence and diversity of weeds under JUN stands in the area of Nusa Bangsa University experimental garden in Cogreg areas need to be studied and identifie for its potential to be used and prevention as well. The method of analysis used in this study was the least squares method of 0,5 $\mathrm{m} \times 0,5 \mathrm{~m}$ and made 10 sample plots under the stand of JUN. Weeds were identified by using the description book based on morphological characteristics, the type, amount and its potential as a medical plant. The results showed that there were 15 types of weeds under JUN stands, namely Oxalis barrelieri, Phyllanthus niruri, Nephrolepis biserata, Ageratum conyzoides, Borreria latifolia, Molineria longiflora, Murdanium nudiflora, Synedrella nodiflora, Acalypha indica L, Echinochloa crus - galli (L.) P. beauv, Commelina diffusa Burm, Asystasia sp. and Clibadium surinamense. Among all the types of weeds, Borreria latifolia were dominant.
\end{abstract}

Keywords : Teak Superior Archipelago (JUN), weeds, identification, medicinal plants

\begin{abstract}
ABSTRAK
Gulma merupakan tumbuhan yang kehadirannya tidak diinginkan karena dapat menurunkan hasil yang dicapai oleh tanaman produksi. Gulma merupakan komponen penting dalam ekosistem hutan yang harus diperhitungkan perannya. Komposisi dan keanekaragaman gulma ikut menentukan struktur hutan yang pada akhirnya akan berpengaruh pada fungsi ekologis hutan. Kehadiran dan keanekaragaman gulma di bawah tegakan JUN di areal kebun percobaan Universitas Nusa Bangsa di daerah Cogreg perlu dipelajari dan diidentifikasi untuk dimanfaatkan potensinya maupun untuk penanggulangan gulma. Metode analisis yang digunakan dalam penelitian ini adalah dengan metode kuadrat $0,5 \mathrm{~m}$ x $0,5 \mathrm{~m}$ dan dibuat 10 petak contoh di bawah tegakan JUN. Gulma diidentifikasi dengan menggunakan buku deskripsi berdasarkan ciri morfologi, jenis, jumlah serta potensinya sebagai tumbuhan obat. Hasil penelitian menunjukkan bahwa terdapat 15 jenis gulma di bawah tegakan JUN, yaitu Oxalis barrelieri, Phyllanthus niruri, Nephrolepis biserata, Ageratum conyzoides, Borreria latifolia, Molineria longiflora, Murdanium nudiflora, Synedrella nodiflora, Acalypha indica L, Echinochloa crusgalli (L.) P. Beauv, Commelina diffusa Burm, Asystasia,sp,dan Clibadium surinamense. Diantara semua jenis gulma tersebut, yang mendominasi adalah Borreria latifolia.
\end{abstract}

Kata Kunci: Jati Unggul Nusantara (JUN), gulma, identifikasi, tanaman obat

\section{PENDAHULUAN}

Pembangunan Hutan Tanaman Industri (HTI) secara langsung maupun tidak langsung dapat merangsang pertumbuhan gulma, karena penanaman dalam bentuk barisan, jarak tanam yang lebar dan bersifat monokultur. Tumbuhan yang lazim sebagai gulma cendrung mempunyai sifat - sifat tertentu yang memungkinkan mudah tersebar luas dan mampu menimbulkan gangguan dan kerugian (Yunasfi, 2007).

Tanaman secara umum dibagi menjadi dua, yaitu tanaman yang menguntungkan dan tanaman yang 
merugikan. Tanaman yang menguntungkan biasanya merupakan tanaman yang sengaja ditanam dan dibudidayakan oleh manusia karena mempunyai nilai ekonomis. Sedangkan tanaman yang merugikan adalah tanaman yang tidak dikehendaki keberadaannya atau dalam bahasa pertanian sering disebut dengan gulma (weed).

Kebun percobaan Universitas Nusa Bangsa di daerah Cogreg, merupakan salah satu tempat yang memungkinkan bagi tumbuhnya berbagai jasad pengganggu seperti gulma. Hal ini dikarenakan pada areal yang luas ini terdapat sumber air dan makanan. Pada areal ini terdapat tegakan Jati Unggul Nusantara (JUN) varietas jati baru yang bersifat fast growing yang didapat melalui proses kultur jaringan. JUN sebagai tegakan mempunyai potensi sebagai elemen penting bagi keberadaan tanaman lain.

Gulma merupakan indikator yang menarik untuk diamati dan diteliti, berbeda dengan hama dan penyakit tanaman, pengaruh yang diakibatkan gulma tidak terlihat secara langsung dan berjalan lambat. Tetapi secara komulatif kerugian yang ditimbulkan sangat besar, karena untuk memenuhi kebutuhan unsure hara, air, sinar matahari, udara dan ruang tumbuh, gulma mampu berkompetisi kuat dengan tanaman lain, (Barus, 2003).

Gulma merupakan komponen penting dalam ekosistem hutan yang harus diperhitungkan perannya. Komposisi dan keanekaragaman gulma ikut menentukan struktur hutan yang pada akhirnya akan berpengaruh pada fungsi ekologis hutan. Kehadiran dan keanekaragaman gulma di areal kebun percobaan Universitas Nusa Bangsa di daerah Cogreg perlu di pelajari dan diidentifikasi untuk dimanfaatkan maupun untuk penanggulangan gulma.

\section{Rumusan Masalah}

Gulma adalah tumbuhan yang kehadirannya tidak diinginkan karena dapat menurunkan hasil yang dicapai oleh tanaman produksi. Gulma merupakan komponen penting dalam ekosistem hutan yang harus diperhitungkan perannya. Komposisi dan keanekaragaman gulma ikut menentukan struktur hutan yang pada akhirnya akan berpengaruh pada fungsi ekologis hutan. Kehadiran dan keanekaragaman gulma di bawah tegakan JUN di areal kebun percobaan Universitas Nusa Bangsa di daerah Cogreg perlu di pelajari dan diidentifikasi untuk dimanfaatkan maupun untuk penanggulangan gulma.

\section{Tujuan Penelitian}

Penelitian ini bertujuan untuk mengetahui jenis - jenis gulma dan potensi gulma yang berada di bawah tegakan pohon jati kebun percobaan UNB, Cogreg, Bogor.

\section{BAHAN DAN METODE}

\section{Lokasi dan Waktu}

Lokasi penelitian dilaksanakan di Kebun Percobaan Universitas Nusa Bangsa, Desa Cogreg, Kecamatan Parung, Kabupaten Bogor; Desember 2011.

\begin{abstract}
Alat dan Bahan
Bahan yang digunakan adalah gulma di bawah tegakan JUN kebun percobaan UNB dan alkohol $70 \%$.

Alat yang digunakan antara lain, meteran, sasak bambu, tali rapia, alat tulis, kantong plastik untuk menyimpan sampel gulma, spidol atau label dan kamera.
\end{abstract}

\section{Metode}

Metode analisis yang digunakan dalam penelitian ini adalah dengan metode kuadrat yang merupakan metode paling sederhana dan sering digunakan. Yang dimaksud "kuadrat" adalah suatu ukuran luas yang diukur dalam suatu kuadrat $\mathrm{m}^{2}$, $\mathrm{cm}^{2}$, berbentuk bujur sangkar, (Dede Setiadi,dkk, 1992). 


\section{Prosedur Pengamatan}

Menentukan dan membuat petak contoh secara acak dengan ukuran $0,5 \mathrm{~m} \mathrm{x}$ $0,5 \mathrm{~m}$ dengan bentuk bujur sangkar.

Jenis gulma yang tumbuh pada petak contoh tersebut dicatat dan diambil untuk diidentifikasi.

Gulma yang didapatkan dimasukkan ke dalam plastik kemudian dipisahkan berdasarkan kesamaannya.

\section{Hal yang sama dilakukan untuk 10 petak.}

Gulma diidentifikasi dengan menggunakan buku deskripsi berdasarkan ciri morfologi, jenis, jumlah serta potensinya sebagai tumbuhan obat.

\section{HASIL DAN PEMBAHASAN}

Hasil pengamatan didapatkan tumbuhan gulma yang tumbuh tidak terlalu rapat, karena di lokasi pengamatan sudah banyak tanaman jati yang tumbuh besar, sehingga tanah sudah terlindungi dan sinar matahari tidak secara langsung menembus ke tanah. Hasil identifikasi dari 10 petak contoh didapatkan terdapat 15 jenis gulma berbeda yang mewakili keanekaragaman gulma yang berada di bawah tegakan JUN kebun percobaan UNB Cogreg seperti terlihat pada Tabel 1.

Tabel 1. Hasil Identifikasi Jenis Gulma pada 10 Petak Contoh

\begin{tabular}{ll}
\hline \multicolumn{1}{c}{ Nomor Petak } & \multicolumn{1}{c}{ Jenis Gulma } \\
\hline Petak-1 & $\begin{array}{l}\text { Borreria latifolia, Cynedrela nudiflora, Imperata } \\
\text { cylindrical, Oxalis barrelieri, Commelina diffusa }\end{array}$ \\
Petak-2 & $\begin{array}{l}\text { Echinochloa crus-galli, Murdanium nudiflora, } \\
\text { Commelina diffusa, Borreria latifolia }\end{array}$ \\
Petak-3 & Borreria latifolia, Asystasia sp, Phyllantus niruri \\
Petak-4 & $\begin{array}{l}\text { Borreria latifolia, Ischaemum timorense, Murdanium } \\
\text { nudiflora, Cynedrela nudiflora }\end{array}$ \\
Acalypha indica, Cynedrela nudiflora, Clibadium \\
surinamense, Ischaemum \\
cylindrical (L.), Oxalis barrelieri
\end{tabular}


Berikut hasil identifikasi 15 jenis tumbuhan gulma tersebut.

\section{Oxalis barrelieri (Calincing)}



Klasifikasi

$\begin{array}{lll}\text { Kingdom } & : \text { Plantae /Tumbuhan } \\ \text { Filum } & : \text { Magnoliophyta } \\ \text { Kelas } & : \text { Magnoliopsida } \\ \text { Bangsa } & : \text { Geraniales } \\ \text { Suku } & : \text { Oxalidaceae } \\ \text { Marga } & : \text { Oxalis } \\ \text { Jenis } & : \text { Oxalis barrelieri }\end{array}$

Oxalis barrelieri memiliki nama daerah belimbing tanah atau calincing (Sunda). Tumbuhan Calincing (Oxalis barrelieri) ini tumbuh di kerimbunan semak-semak yang terlindung dari sinar matahari, di tegalan, kebun, sepanjang tembok dan pagar, pada tanggul kecil dan jalan setapak di hutan. Banyak terdapat di daerah Jawa Barat dan Jawa Tengah. Oxalis barrelieri ini tumbuh di dataran rendah sampai ketinggian $1.300 \mathrm{~m}$. di atas permukaan laut. Tumbuhan Calincing termasuk tumbuhan rendah, tingginya mencapai 10 hingga $50 \mathrm{~cm}$. Daunnya seperti semanggi, berbentuk bujur telur, tumbuh bertiga dalam satu tangkai di ujung. Tangkai batangnya bertingkat, bunganya dalam payung tunggal di ketiak dengan 2 sampai 8 bunga, daun mahkota kuning dengan pangkal hijau, panjang 3 sampai $8 \mathrm{~mm}$. Benang sari di depan daun mahkota lebih pendek dari pada yang lima lainnya. Tankai putik berambut. Bentuk buahnya seperti belimbing manis besarnya sekitar 8 hingga $10 \mathrm{~mm}$, rasanya masam.

Gulma ini selain menjadi tanaman pengganggu di kebun Jati, bisa juga dimanfaatkan sebagai tanaman obat antara lain ; untuk mencegah seseorang keracunan, caranya kita ambil daun calincing, lalu cairannya dikeluarkan dan diminum atau dimasak bersama makanan, menurunkan tekanan darah, sebagai antibiotik, obat penurun panas dan anti inflamasi.

\section{Imperata cylindrica (Alang-alang)}

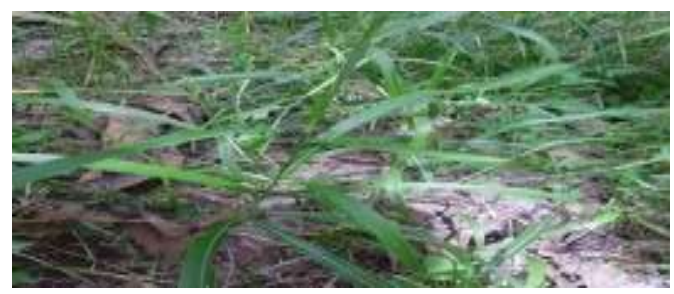

Klasifikasi

$\begin{array}{lll}\text { Kingdom } & : \text { Plantae /Tumbuhan } \\ \text { Filum } & : \text { Magnoliophyta } \\ \text { Kelas } & : \text { Liliopsida } \\ \text { Bangsa } & : \text { Poales } \\ \text { Suku } & : \text { Poaceae } \\ \text { Marga } & : \text { Imperata } \\ \text { Jenis } & : \text { Imperata cylindrical }\end{array}$

Imperata cylindrica memiliki nama daerah Ilalang, Alang-alang (Jawa), Eurih (Sunda) dan Ambengan (Bali). Ilalang merupakan terna rumput berumur panjang (perenial), tumbuh berumpun dengan tinggi $30-180 \mathrm{~cm}$. Akar rimpang menjalar, bagian tumbuhan yang berbuku buku, keras dan liat, dengan bagian dalam berwarna putih. Batang berbentuk silindris berdiameter sekitar $2-3 \mathrm{~mm}$ serta beruasruas. Daun warna hijau, bentuk pita (ligulatus), panjang $12-80 \mathrm{~cm}$, lebar $2-5$ $\mathrm{cm}$, helaian daun tipis tegar, ujung meruncing (acuminatus), tepi rata, pertulangan sejajar (parallel), permukaan atas halus, permukaan bawah kasar (scaber). Bunga majemuk, bentuk bulir (spica), bertangkai panjang, setiap bulir berekor puluhan helai rambut putih sepanjang $8-14 \mathrm{~mm}$, mudah diterbangkan angin. Buah bentuk biji jorong, panjang \pm $1 \mathrm{~mm}$, berwarna cokelat tua. Perbanyakan secara vegetatif.

Gulma ini selain menjadi tanaman pengganggu di kebun Jati, bisa juga dimanfaatkan sebagai tanaman obat antara lain ; orang dayak menggunakan ilalang 
untuk mengobati pendarahan dan sakit gigi. Rimpangnya mengandung asam kersik, damar dan logam alkali. Hasil penelitian di Jepang menunjukkan bahwa pada rimpangnya terdapat senyawa terpenoid iso-arborinol atau $\beta$-arborinol. Secara rinci kandungan bahan pada batang dan rimpang adalah manitol, glukosa, sakarosa, asam malat, asam sitrat, coixol, silindrin, fernenol, simiarenol dan anemonin.

\section{Phyllanthus niruri (Meniran)}

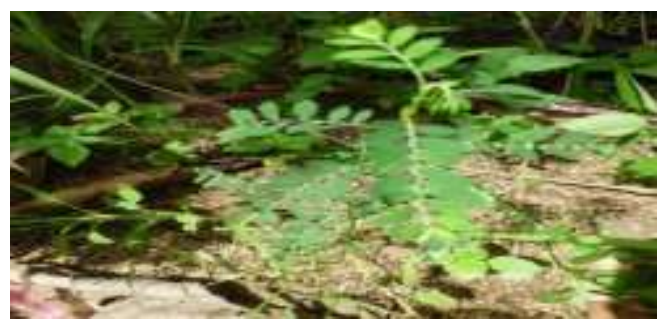

Klasifikasi

$\begin{array}{lll}\text { Kingdom } & : & \text { Plantae /Tumbuhan } \\ \text { Filum } & : \text { Magnoliophyta } \\ \text { Kelas } & : \text { Magnoliopsida } \\ \text { Sub Kelas } & : \text { Rosidae } \\ \text { Bangsa } & : \text { Euphorbiales } \\ \text { Suku } & : \text { Euphorbiaceae } \\ \text { Marga } & : \text { Phyllanthus } \\ \text { Jenis } & : \text { Phyllanthus niruri }\end{array}$

Phyllanthus niruri memiliki nama daerah meniran. Meniran merupakan tumbuhan yang berasal dari daerah tropis yang tumbuh liar di hutan - hutan, ladangladang, kebun - kebun maupun pekarangan halaman rumah, pada umumnya tidak dipelihara, karena dianggap tumbuhan rumput biasa. Meniran tumbuh subur ditempat yang lembab pada dataran rendah sampai ketinggian 1000 meter di atas permukaan laut. Batangnya berbentuk bulat berbatang basah dengan tinggi kurang dari $50 \mathrm{~cm}$, tidak berambut, hijau, diameternya $\pm 3 \mathrm{~mm}$. Daunnya majemuk, berseling, anak daun 15-24, berbentuk bulat telur, ujung tumpul, pangkal membulat, panjang $\pm 1,5 \mathrm{~cm}$, lebar \pm 7 $\mathrm{mm}$, tepi rata, berwarna hijau. Bunganya tunggal, terdapat pada ketiak daun menghadap ke arah bawah menggantung, berwarna putih, daun kelopak bentuk bintang, benang sari dan putik tidak nampak jelas, mahkota bunga kecil, berwarna putih.

Buahnya kotak, bulat pipih, licin, diameter $\pm 2 \mathrm{~mm}$, berwarna hijau keunguan. Bijinya kecil, keras, berbentuk ginjal dan berwarna coklat. Akarnya merupakan akar tunggang, berwarna putih. Penelitian menunjukan zat-zat yang terkandung dalam tumbuhan meniran adalah Filantina, hipofilantina, dan garam kalsium.

Gulma ini selain menjadi tanaman pengganggu di kebun Jati, bisa juga dimanfaatkan sebagai tanaman obat antara lain ; sakit Kuning, air rebusan meniran dicampur susu, kayu manis, temulawak dan cengkeh lalu diminum setiap hari, demam, meniran diseduh dengan air panas kemudian diminum, batuk, air rebusan meniran dicampur madu lalu diminum, disentri, air rebusan meniran diminum dua kali sehari, malaria, air rebusan meniran dicampur kayu manis dan cengkeh lalu diminum dua kali sehari, luka Bakar, air rebusan meniran dicampur temulawak, kayu manis dan cengkeh lalu diminum setiap hari, jerawat, air rebusan meniran dicampur kunyit lalu diminum setiap hari.

\section{Nephrolepis bisserata (Paku Harupat)}

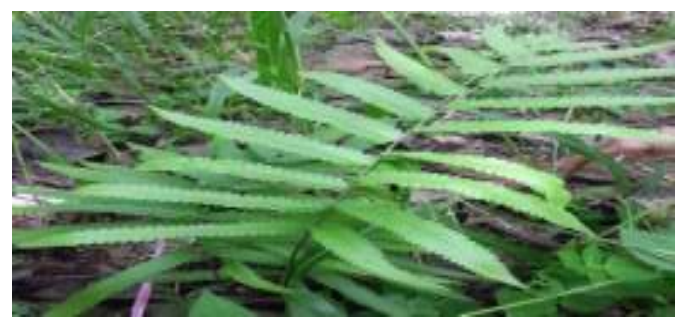

Klasifikasi

$\begin{array}{lll}\text { Kingdom } & : \text { Plantae /Tumbuhan } \\ \text { Filum } & : \text { Pteridophyta } \\ \text { Kelas } & : & \text { Pteridopsida } \\ \text { Sub Kelas } & : \text { Polypoditae } \\ \text { Bangsa } & : \text { Polypodiales } \\ \text { Suku } & : \text { Dryopteridaceae } \\ \text { Marga } & : \text { Nephrolepis } \\ \text { Jenis } & : \text { Nephrolepis bisserata }\end{array}$


Di alam paku ini tumbuh di tempat yang terbuka, kadang - kadang tumbuh di tempat yang terlindung, di dataran rendah yang tidak terlalu kering. Selain hidup di tanah, dijumpai pula di pohon - pohon palem secara epifit, dapat pula tumbuh di sela - sela bebatuan apabila terisi dengan humus. Orang Sunda menyebutnya paku harupat, mungkin karena suka tumbuh di pohon - pohon palem, kata harupat sebenarnya berarti lidi aren. Mungkin juga nama tersebut berasal dari tangkai daunnya yang tegak dan kaku seperti lidi. Nephrolepis dapat ditemukan pada dataran tinggi, daerah kering seperti padang pasir, daerah berair atau area - area terbuka. Selain itu dapat ditemukan 4 tipe habitat Nephrolepis yaitu, hutan rindang yang memiliki celah permukaan berkarang, khususnya yang terlindung dari sinar matahari, terdapat di daerah rawa dan tergenang air dan tumbuh sebagai epifit pada pohon - pohon tropik.

Tangkai daunnya bersisik lembut, sisik - sisik tersebut berwarna coklat, panjang daunnya dapat mencapai $2 \mathrm{~m}$ bila tumbuh di tempat yang cocok. Bentuk daun subur lebih besar dari daun mandul, pada daun subur bentunya lancip dengan dasar yang berkuping. Sporanya terletak dipinggir daun. Jenis ini mudah dibedakan dengan jenis paku lain karena letak sporanya yang tidak merata. Para daun tumbuh hingga sekitar satu meter. Ental pengaturan bergerombol dan ental desain dibagi.

Paku harupat umum tersebar di seluruh daerah Asia tropika. Paku ini jarang ditemukan di lereng - lereng gunung namun menyukai dataran rendah. Daun muda jenis pakis ini dapat dibuat sayur dan dapat dijadikan sebagai tanaman hias sebagai penutup tanah atau hiasan batas.Gulma ini selain menjadi tanaman pengganggu di kebun Jati, bisa juga dimanfaatkan sebagai tanaman obat antara lain : sebagai bahan pembuatan obat cacing,mengobati kanker perut, sebagai obat disentri, infeksi saluran kemih, penurun panas atau demam dan anti bakteridan sebagai sayuran.

\section{Ageratum conyzoides (Babadotan)}

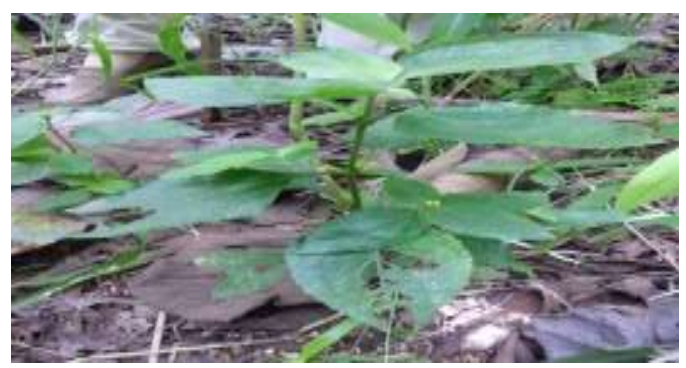

Klasifikasi

$\begin{array}{lll}\text { Kingdom } & : & \text { Plantae } \\ \text { Filum } & : & \text { Magnoliophyta } \\ \text { Kelas } & : & \text { Magnoliopsida } \\ \text { Bangsa } & : & \text { Asterales } \\ \text { Suku } & : & \text { Asteraceae/Compositae } \\ \text { Marga } & : \text { Ageratum } \\ \text { Jenis } & : \text { Ageratum conyzoides }\end{array}$

Tanaman Babadotan yang merupakan salah satu Bioinsektisida yang terdapat di alam bahwa tanaman Babadotan mengandung saponin, flavanoid, polifenol, dan minvak atsiri yang kandungan di dalamnya bermanfaat untuk membasmi hama thrips dengan mekanisme kerja melalui penghancuran pernafasan dan pemutusan rantai kehidupan insekta.

Babadotan yang memiliki nama ilmiah Ageratum conyzoides. Di beberapa daerah tanaman ini dikenal dengan nama jukut bau/babadotan, ki bau (Jawa Barat) dan Billygoat-weed (Inggris). Tanaman ini bisa hidup bebas di alam raya tanpa terlalu banyak memerlukan persyaratan hidup, dengan kata lain tanaman ini dapat hidup pada tanah yang kering dan tanah yang basah dengan suhu panas ataupun dingin ataupun di dataran rendah maupun dataran tinggi.

Tanaman Babadotan tergolong jenis tanaman herbal dengan ciri - ciri umum sebagai berikut : tinggi tumbuhan maksimal $50-60 \mathrm{~cm}$, daun bertangkai, letaknya saling nerhadapan dan bersilang (composite). Helaian daun bulat telur dengan pangkal membulat dan ujung runcing dengan tulang daun menyirip dan tepi daun bergerigi. panjang daun $1-10$ $\mathrm{cm}$, lebar $0,5-6 \mathrm{~cm}$, memiliki bunga 
majemuk dengan ukuran kecil yang tumbuh di ketiak batang dengan warna benang sari putih dan kepala putik kuning, panjang bonggol bunga $6-8 \mathrm{~mm}$, dengan tangkai yang berambut, diameter batang tanaman $0,5-1,2 \mathrm{~cm}$, berakar serabut, kebanyakan cabang tumbuh ke samping atau pertumbuhan lebih condong mendatar (tidak menyilang, tumbuh di ketinggian 1 sampai 2100 meter dari permukaan laut. Dapat tumbuh di sawah - sawah, ladang, semak belukar, halaman kebun, tepi jalan, tanggul, dan tepi sungai.

Gulma ini selain menjadi tanaman pengganggu di kebun Jati, bisa juga dimanfaatkan sebagai tanaman obat antara lain :

1. Sakit telinga tengah akibat radang : Cuci herba bandotan segar secukupnya, lalu tumbuk sampai halus. Hasilnya, peras dan saring. Gunakan air perasan yang terkumpul untuk obat tetes telinga. Sehari 4 kali, setiap kali pengobatan sebanyak 2 tetes.

2. Luka berdarah, bisul, eksim : Cuci herba bandotan segar secukupnya sampai bersih, lalu tumbuk sampai halus. Turapkan ramuan ke bagian tubuh yang sakit, lalu balut dengan perban. Dalam sehari, ganti balutan 3-4 kali. Lakukan pengobatan ini sampai sembuh.

3. Bisul, borok : Cuci satu tumbuhan herba bandotan segar sampai bersih. Tambahkan sekepal nasi basi dan seujung sendok teh garam, lalu giling sampai halus. Turapkan ke tempat yang sakit, lalu balut dengan perban.

4. Rematik (istilah kedokteran : reumatik), bengkak karena keseleo : Sediakan satu genggam daun dan batang muda tumbuhan bandotan segar, satu kepal nasi basi dan 1/2 sendok teh garam. Selanjutnya, cuci daun dan batang muda sampai bersih, lalu tumbuk bersama nasi dan garam. Setelah menjadi adonan seperti bubur kental, turapkan ramuan ke bagian sendi yang bengkak sambil dibalut. Biarkan selama $1-2$ jam, lalu balutan dilepaskan. Lakukan perawatan seperti ini 2-3 kali sehari.

5. Perdarahan rahim, sariawan, bisul, bengkak karena memar : Rebus $10-$ $15 \mathrm{~g}$ herba bandotan dalam dua gelas air bersih sampai tersisa menjadi satu gelas. Setelah dingin, saring dan air saringannya diminum sekaligus. Lakukan 2 - 3 kali sehari.

6. Tumor rahim : Rebus $30-60 \mathrm{~g}$ herba bandotan kering segar atau $15-30 \mathrm{~g}$ herba kering dalam tiga gelas air sampai tersisa menjadi satu gelas. Selain direbus, herba segar dapat juga ditumbuk. Air rebusan atau air perasannya diminum satu gelas sehari.

7. Sakit tenggorokan : (1). Cuci 30-60 $\mathrm{g}$ daun bandotan segar sampai bersih, lalu tumbuk sampai halus. Selanjutnya, peras dan saring. Tambahkan larutan gula batu ke dalam air perasan secukupnya dan aduk sampai rata. Minum ramuan dan lakukan tiga kali sehari. (2). Cuci daun bandotan secukupnya, lalu jemur sampai kering. Selanjutnya, giling sampai menjadi serbuk. Tiupkan serbuk ke dalam tenggorokan penderita.

8. Malaria, influenza : Rebus $15-30 \mathrm{~g}$ herba bandotan kering dalam dua gelas air sampai tersisa menjadi satu gelas. Setelah dingin, saring dan minum sekaligus. Lakukan dua kali sehari.

9. Perut kembung, mulas, muntah : Cuci satu buah tumbuhan bandotan ukuran sedang sampai bersih, lalu potong potong seperlunya. Rebus dalam tiga gelas air sampai tersisa menjadi satu gelas. Setelah dingin, saring dan minum sekaligus. Lakukan pengobatan ini $2-3$ kali sehari sampai sembuh.

10. Perawatan rambut : Cuci, daun dan batang bandotan segar ditumbuk sampai halus. Oleskan hasil tumbukan ke seluruh kulit kepala dan rambut. Tutup kepala dengan sepotong kain. Biarkan selama $2-3$ jam. Selanjutnya, bilas rambut hingga bersih. 


\section{Borriera latifolia (Kentangan)}

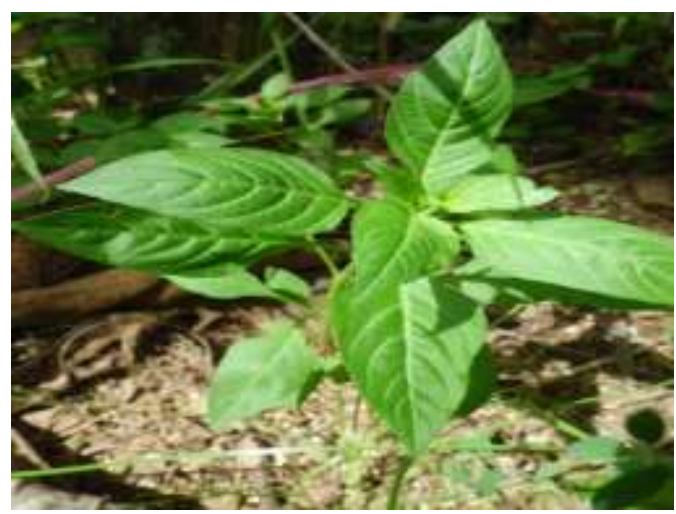

Klasifikasi

$\begin{array}{lll}\text { Kingdom } & : & \text { Plantae } \\ \text { Filum } & : & \text { Magnoliophyta } \\ \text { Kelas } & : & \text { Magnoliopsida } \\ \text { Bangsa } & : & \text { Rubiales } \\ \text { Suku } & : & \text { Rubiaceae } \\ \text { Marga } & : & \text { Borriera } \\ \text { Jenis } & : & \text { Borriera latifolia }\end{array}$

Borreria latifolia Schum (kentangan, rumput setawar) merupakan tumbuhan pengganggu penutup tanah dan pada tanaman muda sering terdapat pada piringan pohon. Jenis rumput ini dapat tumbuh di tempat lembab dan terlindung. Batang tumbuh tegak atau merambat yang dapat mencapai tinggi $15-75 \mathrm{~cm}$ bunga bervvarna hijau muda. Bunga terbentuk di ketiak daun dan ujung batang. Berupa terna atau tumbuhan berkayu dengan daun tunggal atau majemuk yang duduk berhadapan, dengan atau tanpa daun penumpu.

Gulma ini selain menjadi tanaman pengganggu di kebun Jati, bisa juga dimanfaatkan sebagai tanaman obat antara lain : Batu empedu : Herba gempur batu segar 2 genggam; Air $110 \mathrm{ml}$, Dibuat infus atau pipisan, Diminum 2 kali sehari tiap kali minum $100 \mathrm{ml}$; Apabila dibuat pipisan diminum 2 kali sehari; tiap kali minum 1/4 cangkir. Batu ginjal : Herba gempur batu segar 2 genggam; Herba meniran segar 7 pohon; Air $110 \mathrm{ml}$, Dibuat infus, Diminum 2 kali sehari; pagi dan sore; tiap kali minum $100 \mathrm{ml}$.

\section{Asystasia sp}

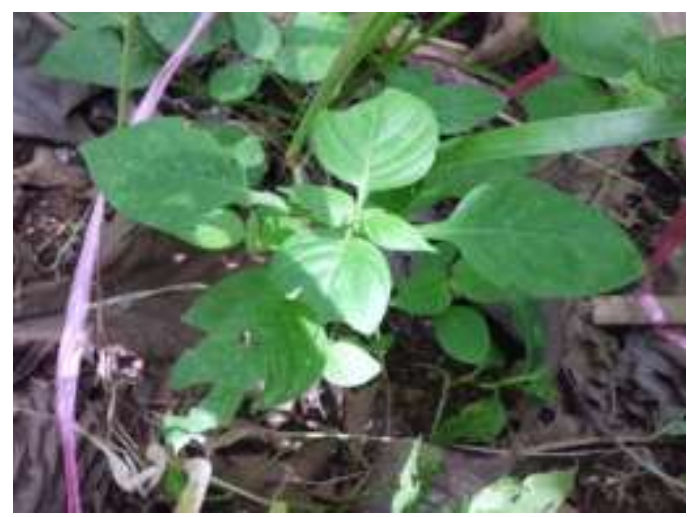

\section{Klasifikasi}

$\begin{array}{lll}\text { Kingdom } & : & \text { Plantae (Tumbuhan) } \\ \text { Filum } & : \text { Magnoliophyta } \\ \text { Kelas } & : \text { Magnoliopsida } \\ \text { Sub Kelas } & : \text { Asteridae } \\ \text { Bangsa } & : \text { Lamiales } \\ \text { Suku } & : \text { Acanthaceae } \\ \text { Marga } & : \text { Asystasia } \\ \text { Jenis } & : \text { Asystasia } s p\end{array}$

Asystasia memiliki toleransi tinggi terhadap kondisi lingkungan yang kurang menguntungkan dan memiliki strategi tertentu untuk mengeksploitasi lingkungan. Pada daerah yang ternaungi, Asystasia akan lebih banyak memproduksi organ vegetatif, sementara pada daerah terbuka akan lebih banyak memproduksi organ generatif. Batang rapuh dengan penampang segi empat dan ditumbuhi rambut-rambut halus yang tersebar secara acak. Tumbuh menjalar dengan cepat mencapai tinggi $0.5 \mathrm{~m}$, dan dapat mencapai $3 \mathrm{~m}$ jika ditopang oleh vegetasi lain. Cabang baru dapat muncul pada ruas batang dan akan menjadi tanaman baru apabila menyentuh tanah. Daun tumbuh berpasangan pada ruas - ruas batang, berbentuk oval mendekati segitiga dengan ujung meruncing. Tangkai daun dapat mencapai panjang $50 \mathrm{~mm}$. Rangkaian bunga muncul pada ujung tunas dan tidak bercabang. Bunga berbentung menyerupai lonceng dengan panjang $20-25 \mathrm{~mm}$ dan memiliki bercak ungu sejajar pada bagian dalam mahkota. 
Kantung biji tersusun pada rangkaian bunga berbentuk gada, berukuran hingga $30 \mathrm{~mm}$ dan mengandung 4 bakal biji berbentuk pipih. Saat biji matang, kapsul akan pecah dan biji akan terpental. Biji diproduksi dalam jumlah banyak dengan viabilitas mencapai $85 \%$ dan dapat bertahan hingga 8 bulan di tanah. Pada kondisi alami, biji dapat berkecambah 30 hari setelah disemai dan tanaman akan mulai tumbuh dengan cepat 10 minggu setelah berkecambah.

\section{Molineria longiflora}

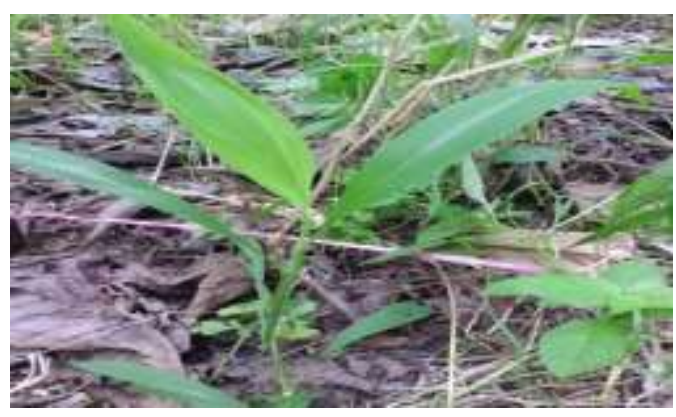

Klasifikasi

$\begin{array}{lll}\text { Kingdom } & : & \text { Plantae (Tumbuhan) } \\ \text { Kelas } & : & \text { Magnoliopsida } \\ \text { Sub Kelas } & : & \text { Liliidae } \\ \text { Bangsa } & : & \text { Asparagales } \\ \text { Suku } & : & \text { Hypoxidaceae } \\ \text { Marga } & : & \text { Molineria } \\ \text { Jenis } & : & \text { Molineria longiflora }\end{array}$

Sejenis tumbuhan berumpun yang hidup di kawasan yang redup dan terlindung dari matahari. Buahnya mempunyai rasa manis sehingga apabila kita minum air atau makan apa saja setelah makan buahnya, semuanya terasa manis. Bagian yang digunakan ialah akar dan buah.

Gulma ini selain menjadi tanaman pengganggu di kebun Jati, bisa juga dimanfaatkan sebagai tanaman obat antara lain :

1. Bagian akarnya berfungsi untuk: mengobati sakit ginjal, menghilangkan sakit perut, mengobati sakit kepala, mengobati malaria, batuk, dengan cara akarnya direbus sehingga mendidih dan diminum

2. Buah lemba yang manis boleh menggantikan gula bagi pengidap kencing manis. Buah lemba yang manis dicampurkan dengan air dan diminum amat sesuai untuk meredakan demam

\section{Murdanium nudiflora (Embun siang)}



Klasifikasi

$\begin{array}{lll}\text { Divisi } & : & \text { Liliopsida } \\ \text { Bangsa } & : \text { Commelinales } \\ \text { Suku } & : \text { Commelinaceae } \\ \text { Marga } & : \text { Murdanium } \\ \text { Jenis } & : \text { Murdanium nudiflora }\end{array}$

Murdanium nudiflora (embun siang) adalah sejenis herbal semusim. Ia adalah sejenis rumpai yang menyerupai rumput tapi hanya mempunyai batang yang menjalar dan akan mengeluarkan bunga kecil berwarna ungu atau biru.Tumbuhan ini membiak secara jalaran rizom dan didapati tumbuh liar dikawasan - kawasan tanah lapang yang ditumbuhi rumbut seperti di kebun - kebun sayur dan pinggir-pinggir belukar. Ia adalah sejenis rumput yang menyerupai rumput tapi ia memiliki batang yang menjalar dan akan mengeluarkan bunga kecil berwarna ungu atau biru.Tumbuhan ini berkembang biak secara jalaran rizom dan tersedia tumbuh liar dikawasan - kawasan tanah lapang yang ditumbuhi rumbut seperti di kebun kebun sayur dan pinggir - pinggir hutan.

Daun berdaging dan linear secara garis besar, sekitar 3/4 sampai 4 inci panjang, 2 sampai $5 \mathrm{~mm}$. Selubung daun memiliki rambut - rambut lembut di pinggiran atas. Batang : Batang tidak 
mudah terlihat, tetapi setelah diteliti lebih jauh, batang dapat dilihat dekat dengan tanah dan perakaran pada node. Akar : Sebuah sistem akar berserat. Bunga : Bunga terjadi dalam kelompok kecil di tangkai bunga pendek (peduncles). Bunga berwarna biru sampai ungu dalam warna dengan kelopak yang 5 sampai $8 \mathrm{~mm}$. Buah : Sebuah kapsul yang 3 sampai 5 mm. Mengidentifikasi Karakteristik : Tanaman dengan berdaging, daun linier yang menyerupai beberapa rumput. Juga, batang merambat dan bunga - bunga biru atau ungu kecil dari gulma membantu untuk mengidentifikasi dari paling gulma sejenis lainnya.

Gulma ini selain menjadi tanaman pengganggu di kebun Jati, bisa juga dimanfaatkan sebagai tanaman obat antara lain : Tumbuhan ini digunakan untuk merawat luka, dengan cara melumatkan tumbuhan ini dan ditampal pada bahagian yang luka.Tumbuhan ini banyak digunakan dalam perubatan herba cina. Penggunaan : Tumbuhan ini digunakan untuk merawat luka dengan cara melumatkan tumbuhan ini dan ditempel pada bagian yang luka.Tumbuhan ini banyak digunakan dalam pengobatan herbal cina.

\section{Ischaemum timorense}

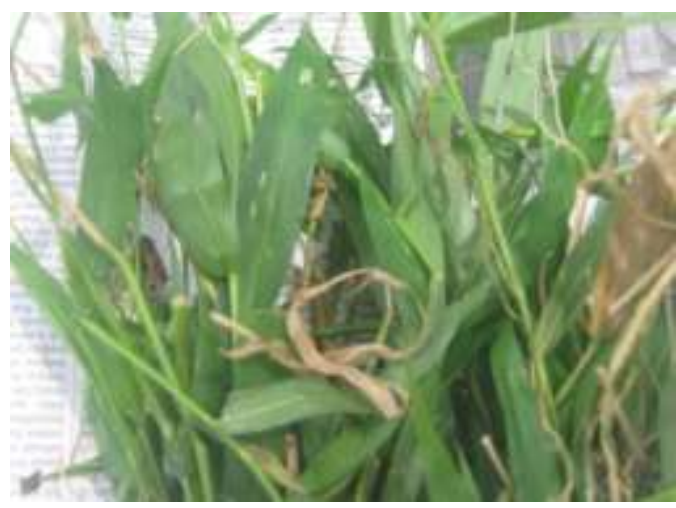

Kalsifikasi

$\begin{array}{lll}\text { Kingdom } & : & \text { Plantae } \\ \text { Kelas } & : & \text { Commelinids } \\ \text { Bangsa } & : & \text { Poales } \\ \text { Suku } & : & \text { Poaceae } \\ \text { Marga } & : \text { Ischaemum } \\ \text { Jenis } & : \text { Ischaemum timorense }\end{array}$

Ischaemum timorense, dikenal dengan nama daerah Lipan rumput, rumput lucuntu (En). Indonesia : jukut jampang manggung (Sunda), rumput apet (Sumbawa). Tumbuhan ini merupakan tumbuhana tahunan, merayap dan perakaran di bagian bawah, tegak, miring atau berebut di bagian atas dengan culms sampai $1 \mathrm{~m}$ tinggi. Daun selubung 3-6 $\mathrm{cm}$, berbulu putih pada node dan seringkali dengan rambut panjang di mulut, margin luar dan bagian belakang; ligule dikelilingi membran pendek, kadang panjang Ciliata; daun lanset pisau linier-lanset, $2-16 \mathrm{~cm} \mathrm{x}$ $3-15 \mathrm{~mm}$, pangkal tumpul atau tangkai seperti, puncak akut, adpressed panjang berbulu, atau gundul di atas. Terminal perbungaan terdiri dari $2(-3)$ racemes erat lawan, masing - masing $2-15 \mathrm{~cm}$; spikelets berpasangan, satu sessile, satu pedicelled; bergantian pada salah satu sisi segitiga rachis; spikelets yang sama, 2berbunga, hijau atau bercampur dengan ungu, bunga kecil jantan lebih rendah, atas bunga kecil biseksual; spiklet 5-7 $\mathrm{mm}$ sessile panjang, di dasar bengkak dan Stipe-suka dan berbulu putih, glume rendah dengan dua lobus akut di puncak, glume atas dengan singkat $2-3 \mathrm{~mm}$ awn panjang, lemma atas 2-lobed dengan panjang 10-16 $\mathrm{mm}$ awn di tengah.

Ischaemum Timorense menetapkan benih dan menyebar dengan stolons berakar. Oleh karena itu umumnya hidup di sepanjang jalan, teras, selokan dan hutan, juga merupakan gulma pada tanaman pertanian. Hal ini ditemukan paling sering di daerah dengan curah hujan tahunan 800 - $2000 \mathrm{~mm}$, tetapi tidak disesuaikan dengan baik situs kering atau terendam air atau tanah berat. Ini tumbuh di bawah penuh atau parsial $(30-50 \%)$ sinar matahari (Ipor et al., 1992).

Ischaemum timorense adalah spesies pakan ternak. Hal ini berguna untuk melindungi tanah terhadap erosi dan dalam menyediakan bahan untuk mulsa, tetapi dapat menjadi gulma pada tanaman tahunan. Khasiat lainnya, belum diketahui. 


\section{Cynedrela nudiflora}

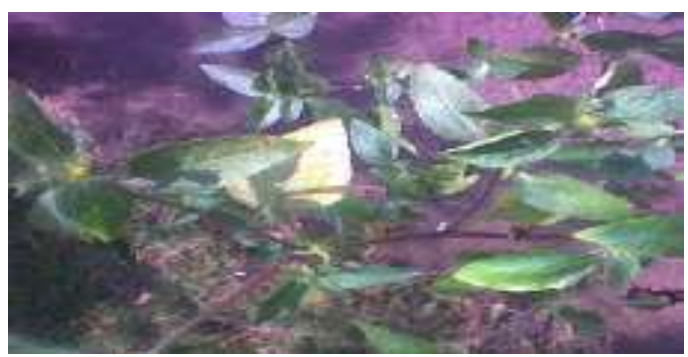

Kalsifikasi :

$\begin{array}{lll}\text { Kingdom } & : & \text { Plantae } \\ \text { Divisi } & : & \text { Magnoliophyta } \\ \text { Kelas } & : & \text { Magnoliopsida } \\ \text { Bangsa } & : & \text { Asterales } \\ \text { Suku } & : & \text { Asteraceae } \\ \text { Marga } & : & \text { Synedrella } \\ \text { Jenis } & : & \text { Synedrella } \text { nudiflora }\end{array}$

Synedrella nudiflora dikenal dengan nama daerah Jotang kuda, merupakan tumbuhan semusim, tegak atau berbaring pada pangkalnya, bercabang menggarpu berulang-ulang; tinggi hingga 1,5 m. Daun - daunnya berhadapan; dengan tangkai bentuk talang, $0,5-5,5 \mathrm{~cm}$, tangkai dari pasangan daun yang sama dihubungkan dengan tepi yang sempit, dengan banyak rambut di sekitarnya. Helai daun bundar telur memanjang, 2,5-15 × 1$9 \mathrm{~cm}$; pangkal daun menyempit sepanjang tangkai, ujung daun runcing, sementara tepinya bergerigi lemah dan berambut di kedua permukaannya. Bunga majemuk dalam bongkol kecil, panjang $8-10 \mathrm{~mm}$, duduk atau bertangkai pendek, berisi 10 20 bunga yang berjejal - jejal; terletak terminal atau di ketiak daun, $1-7$ bongkol bersama - sama. Daun pelindung bundar telur memanjang, berujung runcing, berambut kaku. Bunga tepi $4-8$ buah, dengan pita kuning bertaju $2-3$, 1k $2 \mathrm{~mm}$ panjangnya. Bunganya berbentuk cakram serupa tabung, 6-8 buah, kuning muda dengan taju kuning cerah. Tabung kepala sari coklat kehitaman. Buahnya keras, dengan dua macam bentuk: buah dari bunga tepi sangat pipih, bersayap dan bergerigi runcing di tepi dan ujungnya; sementara buah dari bunga cakram sempit panjang, dengan $2-4$ jarum di ujungnya. Panjang buah $1 \mathrm{k} .0,5 \mathrm{~cm}$.

Daun yang muda kadang - kadang dimanfaatkan sebagai lalab. Daun yang digiling halus bersama daun bandotan (Ageratum conyzoides), daun cente manis (Lantana camara), dan kapur sirih, dioleskan untuk menghangatkan perut yang sakit. Tumbuhan ini juga digunakan sebagai obat gosok untuk meringankan rematik, radang buah dada, batuk dan terkilir.

Synedrella nudiflora mengandung saponin, flavonoida dan polifenol, di samping itu daunnya juga mengandung minyak atsiri.

\section{Acalypha indica}

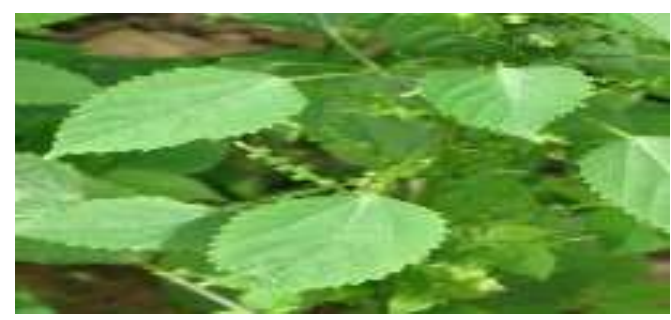

\section{Klasifikasi :}

Kingdom : Plantae /Tumbuhan

Super Divisi : Spermatophyta

Divisi : Magnoliophyta

Kelas : Magnoliopsida

Sub Kelas : Rosidae

Bangsa : Euphorbiales

Suku : Euphorbiaceae

Marga : Acalypha

Jenis : Acalypha indica $\mathrm{L}$.

Acalypha indica dikenal dengan nama daerah, kucing - kucingan, cekamas, lelatang, rumput kokowongan (Sunda), rumput bolong-bolong (Jawa). Tumbuhan ini mempunyai, batang tegak, masif, bulat, berambut, halus, hijau; daun tunggal, tersebar, bentuk belah ketupat, jung runcing, pangkal membulat, tipis, tepi bergerigi, pertulangan menyirip, panjang 3-4 cm, lebar $2-3 \mathrm{~cm}$, tangkai silindris, panjang 3-4 cm, hijau. Bunga majemuk, bentuk bulir, berkelamin satu, di ketiak daun dan ujung cabang, bulir betina lebih pendek, lebih tegak dan lebih jorong dari 
pada bulir jantan, daun pelindung menjari, terbagi dalam $5-15$ taju yang sempit, bunga jantan duduk dalam gelendong sepanjang sumbu bulir, bakal buah beruang tiga, berambut, tangkai putik silindris, putih kehijauan atau merah pucat, mahkota bulat telur, merah, bertaju, berambut, merah. Buah kotak, bulat, hitam, biji bulat panjang, coklat. Akar tunggang. Semak, tinggi $\pm 1,5 \mathrm{~m}$, merupakan gulma yang sangat umum ditemukan tumbuh liar di pinggir jalan, lapangan rumput, maupun di lereng gunung.

Daun Acalypha indica berkhasiat untuk pencahar dan obat sakit mata. pencahar : dipakai \pm 10 gram daun segar Acalypha indica, dicuci, direbus dengan 1 gelas air selama 15 menit, dinginkan dan disaring. Hasil saringan diminum sekaligus. Daun, batang dan akar Acalypha indica mengandung saponin dan tanin; di samping itu batangnya juga mengandung flavonoida; dan daunnya mengandung minyak atsiri, (Dalimartha,S. diakses 19 Jan 2012).

\section{Echinochloa crus-galli (Jajagoan)}

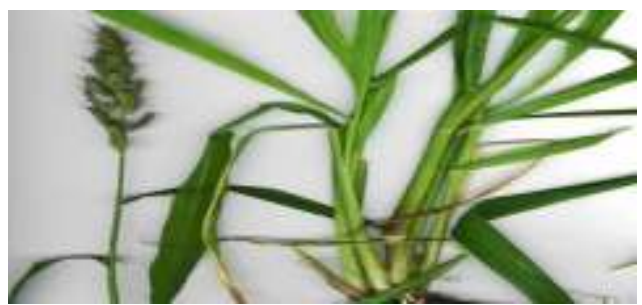

\section{Klasifikasi :}

Kingdom : Plantae /Tumbuhan

Superdivisi : Spermatophyta

Divisi : Magnoliophyta

Kelas : Liliopsida

Bangsa : Cyperales

Suku : Poaceae

Marga : Echinochloa

: Echinochloa crus-galli

Jenis : (L.) P. Beauv.

Echinochloa crus-galli (L.) $P$. Beauv, lumbung rumput, jajagoan, merupakan tumbuhan tahunan $\mathrm{C} 4$, graminoid, non-musiman namun cenderung ke arah hangat struktur: a, berumbai tegak untuk menyebarkan dan semi-sujud, graminoid tahunan, akar: akar berserat, percabangan: culms bebas percabangan di pangkalan dan node yang lebih rendah. sarung: culms 8-16 inci (20$60 \mathrm{~cm}$ ) atau lebih tinggi, gundul atau node atau lebih luas, tidak berbulu, margin jarang scabrous; lembut, agak tipis, longgar, biasanya dengan ungu melintang daun telinga: kerah halus dan tidak berbulu. Tidak ada auricles. perbungaan: perbungaan adalah malai terminal dengan 3 - 7 banyak spasi, appressed atau cabang penyebaran lonjakan seperti racemes, cabang tunggal atau kadang - kadang dipasangkan pada cabang - cabang primer tidak bercabang, malai kebanyakan 1,2-6 inci $(3-15 \mathrm{~cm})$ panjang, bulir: bulir memiliki satu floret terminal sempurna dengan steril bunga kecil di bawah, dengan dua glumes. Spikelets 0.1 in. $(2-3 \mathrm{~mm})$ long, $1-1.5 \mathrm{~mm}$ wide, Bulir 0,1 in $(2-3$ $\mathrm{mm}$ ) panjang, $1-1,5 \mathrm{~mm}$ lebar, bulat telur sampai bulat panjang, awnless tapi runcing. Palea datar, permukaan tekstur mirip dengan lemma subur. biji: caryopsis $1,8 \mathrm{~mm}$, berbentuk bulat panjang. Perakarannya dangkal, tumbuh berumpun, dengan tinggi batang $50-150 \mathrm{~cm}$. Batangnya kuat dan kokoh, tumbuh tegak serta daunnya rata/datar dengan panjang 10-20 cm, lebar 0,5-1 cm. Bentuk garis meruncing ke arah ujung, yang mula mula tumbuh tegak kemudian merunduk, panjang $5-21 \mathrm{~cm}$, terdiri dari $5-40 \mathrm{~cm}$ tandan. Biasanya terbentuk piramid sempit, warna hijau sampai ungu tua. Bulirnya banyak, anak bulir panjang $2-3,5 \mathrm{~mm}$ berambut. Kepala sarinya mempunyai diameter 0,6-0,85 mm. Buah E. crusgalli disebut caryopsis, berbentuk lonjong, tebal, panjang $2-3,5 \mathrm{~mm}$. Biji yang tua berwarna kecoklat - coklatan sampai kehitam - hitaman. Echinochloa crus-galli terdapat di tempat - tempat basah, kadangkadang terdapat juga di tempat setengah basah. Di sawah tumbuh bersama padi, akan tetapi umumnya lebih tinggi dan berbunga lebih dulu dari pada padi (Sundaru et al., 1976). 
Akarnya di rebus dan rebusan diambil untuk meningkatkan energi atau untuk mengobati diare sakit perut dan berdarah.

\section{Commelina diffusa Burm (Aur-aur)}

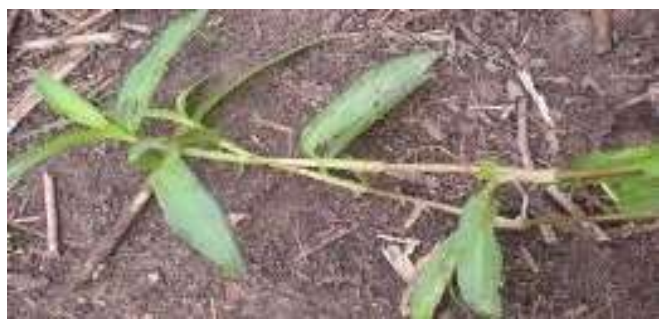

$\begin{array}{ll}\text { Klasifikasi } & : \\ \text { Kingdom } & \text { : Plantae } \\ \text { Super Divisi } & \text { : Spermatophyta } \\ \text { Divisi } & \text { : Magnoliophyta } \\ \text { Kelas } & \text { : Liliopsida } \\ \text { Bangsa } & \text { : Commelinales } \\ \text { Suku } & \text { : Commelinaceae } \\ \text { Marga } & \text { : Commelina } \\ \text { Jenis } & \text { : Commelina diffusa } \text { Burm. }\end{array}$

Commelina diffusa, dikenal dengan nama aur - aur, gewor lalakina (Sunda), brambangan (Jawa), tumbuh menjalar, bentuknya bulat dan lunak, tidak berambut, warnanya hijau muda bercorak ungu, buku-bukunya mengeluarkan akar dan tunas cabang, bagian ujung batang tagak atau melengkung tingginya $5-60$ $\mathrm{cm}$. helai daun berbentuk lanset umumnya berukuran panjang kurang dari enam kali lebarnya, permukaannya licin, pangkalnya berbentuk bundar dan tidak simetris, ujungnya agak runcing, tepinya terasa kasar bila diraba, ukurannya $2,5-8 \mathrm{~cm}$ panjang dan 0,75-2,5 cm lebar. Karangan bunga berdiri sendiri, bertangkai, serupa bungacabang berseling, dengan dua cabang; cabang paling belakang jauh di luar daun pelindung, berbunga $1-3$, panjang $1-2 \mathrm{~cm}$; cabang paling muka lebih pendek, berbunga $2-5$, panjang $0.5-$ $1 \mathrm{~cm}$. Daun pelindung berbentuk jantung, dengan tepi bebas dan ujung meruncing, panjang $1-3 \mathrm{~cm}$. Bunga zygomorph, berumur pendek. Daun kelopak 3, tipis, panjang 3-4 mm, yang paling belakang lebih sempit, yang paling muka 2 pada pangkalnya melekat. Daun mahkota 3, bebas, panjangnya $0.5-1 \mathrm{~cm}$, berwarna biru cerah, yang paling belakang berkuku, yang paling muka duduk, lebih kecil. Bakal buah beruang 3. buah kotak, memanjang, panjang kurang lebih $7 \mathrm{~mm}$, pecah menurut ruang, berisi $3-5$ bij. Biji bertonjolan bentuk jala. Hidup terutama di daerah lembab atau becek, dengan ketinggian $1-2000 \mathrm{~m}$. Umumnya ditemukan di tanah lembab, di sepanjang selokan, limbah di darat dan di bawah bambu, pada tanah yang kaya humus tanah liat. Daunnya digunakan untuk obat luka, demam, sakit kepala dan peluruh keringat. Daunnya mengandung saponin, polifenol dan flavonoida.

\section{Clibadium surinamense (Kiangsrat)}

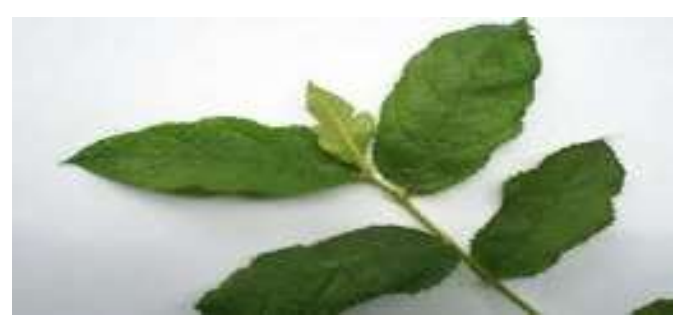

$\begin{array}{lll}\text { Klasifikasi } & & \\ \text { Kingdom } & : & \text { Plantae } \\ \text { Phylum } & : & \text { Tracheophyta } \\ \text { Kelas } & : & \text { Magnoliopsida } \\ \text { Bangsa } & : & \text { Asterales } \\ \text { Suku } & : & \text { Compositae } \\ \text { Marga } & : & \text { Clibadium } \\ \text { Jenis } & : \text { Clibadium surinamense }\end{array}$

Tumbuhan tahunan, yang dikenal dengan nama kiangsrat/kirinyu. Berbentuk semak belukar dengan tinggi dapatmencapai $6-8 \mathrm{~m}$. Letak daun berhadapan, merah kecoklatan pada waktu muda dan mengeluarkan aroma bila diremas. Bunga seragam mempunyai jumlah $20-35$ buah. Kiangsrat tumbuh di berbagai jenis tanah pada ketinggian 50$1000 \mathrm{~m}$ dpl.

Tumbuhan ini digunakan sebagai obat untuk menyembuhkan luka dan menghambat kanker. Kandungan yang terdapat pada tumbuhan ini adalah, senyawa tanin, polifenol, kuinon, flavonoid, steroid, triterpenoid, 
monoterpen dan seskuiterpen flavonoid, tanindan steroid.

Beberapa jenis gulma pada lokasi pengamatan, berpotensi sebagai obat obatan, seperti Oxalis barrelieri, untuk mencegah keracunan, menurunkan tekanan darah, sebagai antibiotik, obat penurun panas dan anti inflamasi; Imperata cylindrical mengobati pendarahan dan sakit gigi; Phyllanthus niruri sakit kuning, demam, batuk, disentri, malaria, luka bakar dan mengobati jerawat; Nephrolepis biserata sebagai bahan obat cacing, obat disentri, infeksi saluran kemih, penurun panas atau demam dan anti bakteri; Ageratum conyzoides, untuk mengobati radang telinga, bisul, eksim, rematik, seriawan, malaria, perut kembung, dll; Borreria latifolia, untuk pengobatan batu ginjal; Molineria longiflora, untuk mengobati sakit kepala, ginjal, kencing manis, batuk, malaria; Murdanium nudiflora, untuk mengobati luka; Synedrella nodiflora, obat gosok untuk meringankan rematik, batuk, terkilir; Acalypha indica L, obat pencahar dan obat sakit mata; Echinochloa crus-galli (L.) P. Beauv, sebagai obat diare; Commelina diffusa Burm, sebagai obat luka, demam, sakit kepala dan peluruh keringat; : Asystasia,sp, untuk mengobati luka dan sakit otot; Clibadium surinamense, untuk menyembuhkan luka dan menghambat perkembangan sel kanker.

Sebaran 15 jenis gulma di bawah tegakan JUN tersebut menunjukkan bahwa jenis gulma Boreria latifolia, yang paling banyak dijumpai yaitu terdapat pada 8 dari 10 petak contoh pengamatan atau hampir terdapat pada semua petak contoh. Sedangkan 5 jenis gulma lainnya, yaitu Phyllantus niruri,Acalyphaindica, Nephrolepis biserata, Molineria longiflora, Ageratum connyzoides, masing - masing hanya dijumpai pada 1 petak contoh pengamatan (Gambar 1). Hal ini disebabkan pada area pengamatan sudah dibersihkan dari gulma dan tumbuhan gulma yang tumbuh tidak terlalu rapat.
Klasifikasi gulma terhadap hasil pengamatan berdasarkan pada habitatnya maka merupakan gulma daratan dan klasifikasi berdasarkan morfologinya dijumpai jenis gulma yang berdaun sempit, seperti Imperata cylindrica, berdaun lebar, seperti Ageratum connyzoides dan paku pakuan seperti, Nephrolepis biserata. Sedangkan jenis gulma teki - tekian tidak dijumpai pada 10 petak contoh pengamatan. Klasifikasi gulma hasil pengamatan berdasarkan siklus hidupnya, dijumpai gulma yang bersifat gulma tahunan, lebih dari dua tahun dan mungkin tidak terbatas (menahun). Jenis gulma ini kebanyakan berkembang biak dengan biji, meskipun ada juga yang berkembangbiak secara vegetatif. Gulma tahunan dapat menyesuaikan diri dengan lingkungan, seperti misalnya, pada musim kemarau jenis gulma ini seolah - olah mati karena ada bagian yang mengering, namun bila ketersediaan air cukup, gulma akan segera bersemi kembali. Jenis ini diantaranya Cynodon dactylon, Cyperus rotundus, Imperata cylindrica (Barus, 2003).

Klasifikasi gulma berdasarkan pengaruhnya terhadap tanaman perkebunan, maka jenis - jenis gulma hasilpengamatan dapat digolongkan ke dalam gulma kelas A yaitu jenis - jenis gulma yang sangat berbahaya bagi tanaman perkebunan sehingga harus diberantas secara tuntas, sepertiImperata cylindrica; gulma kelas $\mathrm{C}$ yaitu jenis jenis gulma yang merugikan tanaman perkebunan dan memerlukan tindakan pengendalian, namun tindakan pengendalian tersebut tergantung pada keadaan, misalnya ketersediaan biaya atau mempertimbangkan segi estetika (kebersihan kebun), seperti Boreria latifolia, Nephrolepsis bisserata dan gulma kelas D yaitu jenis - jenis gulma yang kurang merugikan tanaman perkebunan, namun tetap memerlukan tindakan pengendalian contohnya adalah Ageratum conyzoides (Barus,2003). 


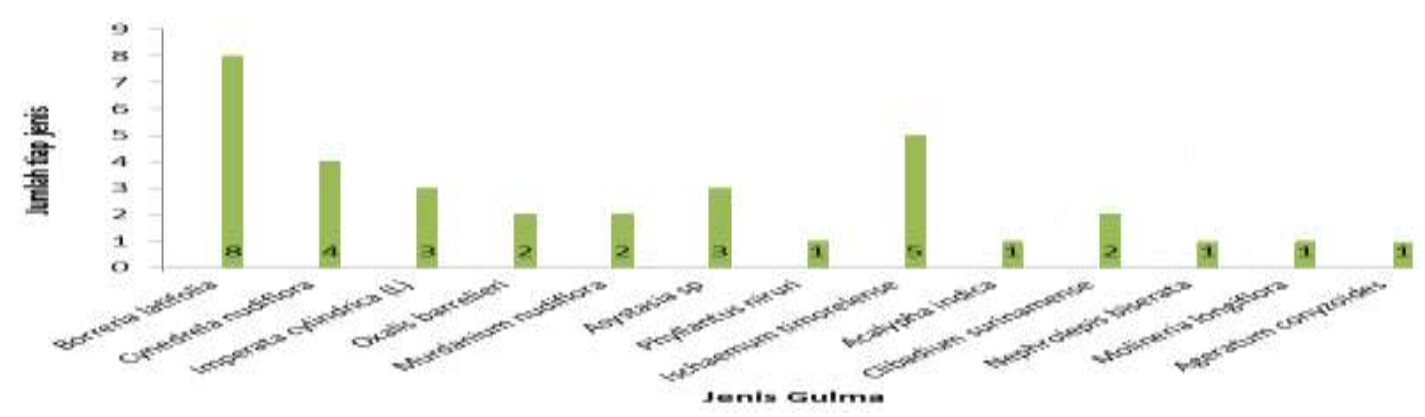

Gambar 1. Sebaran Jenis Gulma di bawah Tegakan JUN pada 10 Petak Contoh

\section{KESIMPULAN DAN SARAN}

\section{Kesimpulan}

Tumbuhan gulma yang paling banyak di jumpai jenis gulma Borreria latifolia yang terdapat pada hampir semua petak contoh.

Gulma selain sebagai tumbuhan pengganggu yang harus diberantas juga mempunyai potensi sebagai tumbuhan obat seperti ;Oxalis barrelieri, Phyllanthus niruri, Nephrolepis biserata, Ageratum conyzoides, Borreria latifolia, Molineria longiflora, Murdanium nudiflora, Synedrella nodiflora, Acalypha indica L, Echinochloa crus-galli (L.) P. Beauv, Commelina diffusa Burm, Asystasia,sp. dan Clibadium surinamense.

Tumbuhan gulma yang tumbuh tidak terlalu rapat, karena lokasi pengamatan sudah banyak tanaman jati yang sudah besar, sehingga tanah sudah terlindungi dan sinar matahari tidak secara langsung menembus ke tanah.

\section{Saran}

Dari hasil yang diperoleh selama pengamatan, perlu dilakukan penelitian lebih lanjut terhadap potensi gulma yang terdapat pada kebun percobaan. UNB, terhadap kandungan dari jenis gulma yang berpotensi sebagai obat.

\section{DAFTAR PUSTAKA}

Barus, Emanuel, 2003. Pengendalian Gulma di Perkebunan. Penerbit Kanisius, Yogyakarta.
Dalimartha, S., (.....). Atlas Tumbuhan Obat Indonesia, diakses tanggal 19 Januari 2012.

Heyne. K, 1987. Tumbuhan Berguna Indonesia, jil. 3:1838. Terj. Yayasan Sarana Wana Jaya, Jakarta.

Pudyatmoko, S., 1997, Variasi Komunitas Tumbuhan Bawah Pada Tegakan Jati Pola Management Regime, diakses tanggal 19 Januari 2012.

Setiadi, D., Ignatius Muhadiono, Ibnul Qayim,1992, Penuntun Pratikum dasar - dasar Ekologi, Laboraboratorium Ekologi, Jurusan Biologi, F MIPA, IPB, Bogor.

Sundaru, M. Syam, M. J. Bakar, 1976. Beberapa Jenis Gulma Padi Sawah. Lembaga Pusat Penelitian Pertanian Bogor, Buletin Tehnik No. 1.

Van Steenis, C. G. G. J., 1997. Flora Untuk Sekolah di Indonesia. PT Pradnya Paramita, Jakarta.

Yunasfi, 2007. Permasalahan Hama, Penyakit dan Gulma Dalam Pembangunan Hutan tanaman Industri dan Usaha Pengendaliannya, Dep. Kehutanan. Fak Pertanian. USU. Medan.2 